\title{
ЕКСПЕРИМЕНТАЛЬНЕ ОБГРУНТУВАННЯ ЕФЕКТИВНОСТІ ЗАСТОСУВАННЯ ЗАСОБІВ МАТЕМАТИЧНОГО МОДЕЛЮВАННЯ ДЛЯ ФОРМУВАННЯ ІНФОРМАЦЙННӦ̈ КУЛЬТУРИ МАЙБУТНЬОГО ЛІКАРЯ
}

\author{
Остапенко Е. М. \\ викладач кафедри біологічної фізики, медичної апаратури та інформатики \\ Вінницький національний медичний університет імені М. I. Пирогова \\ вул. Пирогова, 56, Вінниця, Україна \\ orcid.org/0000-0001-8264-6304 \\ ostemiliya13@gmail.com
}

\begin{abstract}
Ключові слова: інформаціійна культура, майбутній лікар, фахова підготовка, організаційно-педагогічні умови формування інформачійної культури майбутнього лікаря засобами математичного моделювання, педагогічний експеримент.
\end{abstract}

\begin{abstract}
У статті викладено послідовність проведення педагогічного експерименту й аналіз його результатів щодо перевірки ефективності формування інформаційної культури майбутнього лікаря засобами математичного моделювання. Констатувальний етап експерименту включав: збирання даних, потрібних для проведення дослідження; розроблення критеріїв, показників і рівнів сформованості інформаційної культури. Для досягнення цього зі студентами Вінницького національного медичного університету імені М.I. Пирогова проводилися бесіди та тестування. Під час цього етапу педагогічного експерименту були вибрані основні педагогічні засоби і методи, що використовуються в практиці для формування інформаційної культури майбутнього лікаря, було застосовано цілеспрямоване педагогічне спостереження, анкетування, опитування, бесіди. Питання носили переважно проєктний характер, студенти моделювали ситуацію, уявляли свою поведінку і власні дії. Дослідження, проведені під час констатувального етапу педагогічного експерименту, показали, що вихідний рівень сформованості інформаційної культури майбутнього лікаря в експериментальній i контрольній групах наближено однаково низький за всіма компонентами. На формувальному етапі педагогічного експерименту здійснювалося дослідження рівня сформованості інформаційної культури майбутнього лікаря засобами математичного моделювання за такими критеріями: інформаційним, техніко-технологічним, загальнофізичним, творчим, рефлексивним та вербальним. Аналіз результатів експерименту дає змогу констатувати, що використання у навчанні студентів медичних ЗВО запропонованих організаційно-педагогічних умов і моделі позитивно позначається на формуванні інформаційної культури майбутнього лікаря засобами математичного моделювання. В експериментальній групі спостерігалося збільшення кількості студентів із високим і середнім рівнями сформованості інформаційної культури майбутнього лікаря, що підтверджує висунуту гіпотезу.
\end{abstract}




\title{
EXPERIMENTAL SUBSTANTIATION OF EFFICIENCY OF APPLICATION OF MATHEMATICAL MODELING MEANS FOR INFORMATION CULTURE OF THE FUTURE DOCTOR FORMATION
}

\author{
Ostapenko E. M. \\ Lecturer at the Department of Biological Physics, Medical Equipment and Informatics \\ National Pirogov Memorial Medical University, Vinnytsya \\ Pyrogova str., 56, Vinnytsya, Ukraine \\ orcid.org/0000-0001-8264-6304 \\ ostemiliya13@gmail.com
}

\begin{abstract}
Key words: informational culture, future doctor, professional training, organization and pedagogical conditions of future doctor's information culture formation by means of a mathematical model, pedagogical experiment.
\end{abstract}

\begin{abstract}
The article highlights the sequence of the pedagogical experiment and its results analysis concerning the revision of the effectiveness of the future doctor's informational culture formation by means of a mathematical model. The ascertaining stage of the experiment included: collecting the data required for the study; development of criteria, indicators and levels of information culture formation. In order to achieve this, interviews and testing with students of Vinnytsia National Medical University named after M. I. Pyrohov have been conducted. During this stage of the pedagogical experiment, the main pedagogical tools and methods used in practice to form the information culture of the future doctor have been selected, targeted pedagogical observation, questionnaires, surveys, interviews have been used. The questions were mostly of a project nature. Students modeled the situation, imagined their behavior and their own actions. Studies conducted during the ascertaining stage of the pedagogical experiment showed that the initial level of formation of the information culture of the future doctor in the experimental and control groups is approximately equally low for all components. At the formative stage of the pedagogical experiment, a study of the level of formation of the information culture of the future doctor by means of mathematical modeling has been carried out according to the following criteria: informational, technical-technological, general physical, creative, reflective and verbal. The analysis of the results of the experiment allowed to state that the use of the proposed organizational and pedagogical conditions and models in the teaching of students of higher educational establishments has a positive effect on the formation of information culture of the future doctor by means of mathematical modeling. In the experimental group there was an increase in the number of students with a high and medium level of information culture of the future doctor, which confirms the research hypothesis.
\end{abstract}

Постановка проблеми. Сучасний етап розвитку суспільства проходить під знаком переходу від індустріального до інформаційного. Із кожним роком збільшується рівень інформатизації всіх сфер життєдіяльності. У період становлення нового суспільства зростання обсягів інформації відбувається зі значною швидкістю. Темпи інформатизації диктують особливі вимоги до системи професійної освіти, ставлячи перед нею завдання формування особистості, готової до оновлення знань упродовж усього життєвого шляху. Сучасному випускникові необхідні вміння 3 відповідним рівнем компетентності адаптуватися до будьякої зміни в професійній діяльності та приймати рішення на основі достовірної та точної інформа- ції. Професійна освіта нині має дати майбутнім лікарям навички роботи з інформацією, вміння самостійно та швидко орієнтуватися всередині інформаційних ресурсів. Соціальні очікування суспільства від системи професійної освіти поява висококваліфікованого фахівця, який володіє потребою та готовністю самостійно і творчо розв'язувати професійні завдання, наділений розвиненою інформаційною культурою.

Аналіз останніх досліджень і публікацій. Використання математичного моделювання у професійній підготовці позитивно впливає на формування інформаційної культури майбутнього лікаря, на опанування студентами медичних ЗВО професійних знань та прийомів фахової розумової 
діяльності за реалізації таких організаційно-педагогічних умов: теоретичне обгрунтування та розроблення моделі формування інформаційної культури майбутнього лікаря засобами математичного моделювання; створення інформаційного освітнього середовища медичного університету для формування інформаційної культури майбутнього лікаря; моделювання професійних медичних ситуацій із метою формування інформаційної культури студентів медичного університету; використання інформаційно-комунікаційних та Інтернет-технологій із метою формування інформаційної культури майбутнього лікаря.

Грунтуючись на аналізі теоретичних джерел та освітньої практики медичних ЗВО щодо впровадження організаційно-педагогічних умов і моделі формування інформаційної культури майбутнього лікаря засобами математичного моделювання, експериментальна робота проводилася 32015 до 2020 р. на базі кафедри біологічноїфізики, медичної апаратури та інформатики Вінницького національного медичного університету імені М.I. Пирогова.

«У культурології інформаційна культура розуміється в широкому та вузькому аспектах. У широкому аспекті вона охоплює сукупність усіх цінностей в інформаційній сфері, створених людством протягом різних етапів історичного розвитку: появи писемності; документального періоду; поєднання усних і письмових форм інформаційної культури; широкого впровадження комп'ютерних технологій, що зумовлювало також зміни способів мислення та діяльності людини (онтологічний підхід). У вузькому сенсі слова інформаційна культура - це оптимальні засоби маніпулювання знаками, даними, інформацією та подання їх зацікавленому споживачеві для вирішення теоретичних і практичних завдань (праксеологічний підхід)» [13, с. 129].

На думку М. Кадемії, «інформаційна культура - це сукупність системних відомостей про: a) основні методи представлення і добування знань; б) уміння і навички, застосування їх на практиці. Ці пункти реалізуються з використанням IKT (перш за все Інтернету) для розв'язання і постановки змістовних завдань. Іншими словами, інформаційна культура - це культура поводження зі знаннями, даними й інформацією, які зосереджені в комп'ютерах мережі Інтернет» [5, с. 156].

Нині є всі підстави стверджувати про формування нової інформаційної культури [1], що може стати елементомзагальної культури людства. Інформаційна культура поки що є показником загальної, а скоріше, професійної культури, але згодом стане важливим чинником розвитку кожної особистості.

Найбільш близьким до правильного, всебічного визначення поняття «інформаційна культура», 3 точки зору академіка НАПН України, професора Р. Гуревича, $є$ таке: «... ступінь досконалості людини, суспільства або певної його частини в усіх можливих видах роботи 3 інформацією: iї одержанні, накопиченні, побудовані і перероблені будь-якого роду, в створенні на цій основі якісно нової інформації, iï передаванні, практичному використанні» [3, с. 44].

$\mathrm{y}$ багатьох наукових виданнях, у роботах науковців (С. Антонова, Н. Баловсяк, В. Биков, Н. Гендина, С. Гончаренко, А. Гречихін, Р. Гуревич, Н. Зінов'єва, А. Коломієць, В. Кравець, В. Кухаренко, М. Левина, В. Мозолин, М. Назаренко, О. Немиров, Н. Новожилова, С. Оленєв, Є. Семенюк, С. Силаєва, В. Шолохович та ін.) розробляються та досліджуються методики ефективного формування інформаційної культури здобувачів освіти, аналізуються форми освітньої діяльності, доцільність застосовування засобів і прийомів розвитку інформаційної культури на продуктивність навчання та майбутньої професійної діяльності. Водночас у дослідженнях науковців недостатньо досліджено питання взаємозалежності інформаційної культури майбутнього лікаря та якості навчання в контексті сучасної освітньої парадигми.

Аналіз психолого-педагогічних напрацювань науковців дає підстави стверджувати, що в них зібрано значний науковий і практичний досвід, що може бути основою для поліпшення формування інформаційної культури майбутнього лікаря.

Педагогічний експеримент, проведений за результатами якісного та кількісного аналізу, надав можливість перевірити ефективність організаційно-педагогічних умов і моделі формування інформаційної культури майбутнього лікаря засобами математичного моделювання, створених в освітньому процесі медичного 3ВО з метою формування у майбутнього лікаря інформаційної культури.

На першому етапі дослідження було проведено констатувальний етап педагогічного експерименту, мета якого полягала у визначенні початкового рівня сформованості інформаційної культури майбутньоголікаря засобами математичногомоделювання.

Констатувальний експеримент містив два етапи:

1) збирання інформації про фактичний стан досліджуваної проблеми;

2) вибір методики для визначення початкового рівня сформованості інформаційної культури майбутнього лікаря.

Під час цього етапу педагогічного експерименту були вибрані основні педагогічні засоби і методи, що використовуються в практиці для формування інформаційної культури майбутнього лікаря, було застосовано цілеспрямоване педагогічне спостереження, аналіз навчального плану та робочої програми підготовки лікарів, анкетування, опитування, бесіди. 
У плануванні, проведенні педагогічного експерименту, опрацюванні результатів і визначенні ефективності дослідних умов керувалися рекомендаціями як класичних досліджень, так і дослідженнями у сфері діагностики інформаційної культури $[2 ; 3 ; 6-10 ; 12]$.

Метою статті $€$ проведення й аналіз результатів педагогічного експерименту щодо перевірки ефективності організаційно-педагогічних умов і моделі формування інформаційної культури майбутнього лікаря засобами математичного моделювання.

Виклад основного матеріалу дослідження. Анкетування проводилося серед студентів першого, другого та третього курсів медичного факультету № 1, медичного факультету № 2 і стоматологічного факультету Вінницького національного медичного університету імені М.I. Пирогова, опитування - серед викладачів кафедри біологічної фізики, медичної апаратури та інформатики Вінницького національного медичного університету імені М.І. Пирогова; бесіди - зі студентами різних курсів і спеціальностей Вінницького національного медичного університету імені М.I. Пирогова.

Для виявлення початкового рівня сформованості інформаційної культури майбутніх лікарів було проведено анкетування серед студентів першого, другого та третього курсів медичного факультету № 1, медичного факультету № 2 i стоматологічного факультету Вінницького наці- онального медичного університету імені M.I. Пирогова. Інструментом збирання даних констатувального етапу педагогічного експерименту вибрано анкету «Визначення рівня сформованості інформаційної культури».

Аналіз одержаних даних дав змогу зробити висновок, що студенти дослідних груп мають наближено однакові рівні інформаційної культури, практично однакові недоліки під час оброблення інформації.

Було відзначено, що студенти під час виконання освітніх завдань, індивідуальної роботи (IPC), самостійної роботи (СРС), підготовки до заліків, диференційованих заліків та іспитів звертаються за допомогою до Інтернету, а не до традиційних джерел інформації на паперовому носії, що призводить до спотворення достовірності використовуваної інформації. До того ж мало хто зі студентів під час роботи 3 джерелами інформації звертає увагу на інтелектуальні права власності.

Для проведення педагогічного експерименту було створено дві дослідні групи загальною кількістю 434 особи (експериментальна (ЕГ), що налічувала 219 респондентів і контрольна (КГ), у якій проходили навчання 215 респондентів) серед студентів першого-третього курсів медичного факультету № 1, медичного факультету № 2 і стоматологічного факультету Вінницького національного медичного університету імені М.І. Пирогова.

Таблиця 1

Результати у студентів ЕГ і КГ показників сформованості інформаційної культури майбутнього лікаря за критеріями (жовтень 2017 р., констатувальний етап педагогічного експерименту)

\begin{tabular}{|c|c|c|c|c|c|c|c|}
\hline \multirow{3}{*}{ 胥 } & \multirow{3}{*}{$\begin{array}{c}\text { Загальна } \\
\text { кількість } \\
\text { студентів } \\
\text { у групі }\end{array}$} & \multicolumn{6}{|c|}{ Рівні } \\
\hline & & \multicolumn{2}{|c|}{ низький } & \multicolumn{2}{|c|}{ середній } & \multicolumn{2}{|c|}{ Високий } \\
\hline & & Кількість & $\begin{array}{c}\text { \% від загаль- } \\
\text { ної кількості } \\
\text { студентів } \\
\end{array}$ & Кількість & $\begin{array}{c}\text { \% від загаль- } \\
\text { ної кількості } \\
\text { студентів }\end{array}$ & Кількість & $\begin{array}{c}\% \text { від загаль- } \\
\text { ної кількості } \\
\text { студентів } \\
\end{array}$ \\
\hline \multicolumn{8}{|c|}{ за інформаційним критерієм } \\
\hline $\mathrm{E} \Gamma$ & 219 & 133 & 60,73 & 79 & 36,07 & 7 & 3,20 \\
\hline КГ & 215 & 130 & 60,47 & 77 & 35,81 & 8 & 3,72 \\
\hline \multicolumn{8}{|c|}{ за техніко-технологічним критерієм } \\
\hline $\mathrm{E} \Gamma$ & 219 & 134 & 61,19 & 80 & 36,53 & 5 & 2,28 \\
\hline КГ & 215 & 131 & 60,93 & 78 & 36,28 & 6 & 2,79 \\
\hline \multicolumn{8}{|c|}{ за загальнофізичним критерієм } \\
\hline $\mathrm{E} \Gamma$ & 219 & 125 & 57,08 & 85 & 38,81 & 9 & 4,11 \\
\hline КГ & 215 & 123 & 57,21 & 84 & 39,07 & 8 & 3,72 \\
\hline \multicolumn{8}{|c|}{ за творчим критерієм } \\
\hline $\mathrm{E} \Gamma$ & 219 & 130 & 59,36 & 81 & 36,99 & 8 & 3,65 \\
\hline КГ & 215 & 126 & 58,60 & 80 & 37,21 & 9 & 4,19 \\
\hline \multicolumn{8}{|c|}{ за рефлексивним критерієм } \\
\hline $\mathrm{E} \Gamma$ & 219 & 128 & 58,45 & 82 & 37,44 & 9 & 4,11 \\
\hline КГ & 215 & 125 & 58,14 & 80 & 37,21 & 10 & 4,65 \\
\hline \multicolumn{8}{|c|}{ за вербальним критерієм } \\
\hline $\mathrm{E} \Gamma$ & 219 & 131 & 58,45 & 81 & 37,44 & 7 & 4,11 \\
\hline КГ & 215 & 130 & 58,14 & 79 & 37,21 & 6 & 4,65 \\
\hline
\end{tabular}


Результати визначення у студентів ЕГ і КГ показників сформованості інформаційної культури майбутнього лікаря за критеріями наведено в табл. 1.

Перед тим як простежити сформованість інформаційної культури майбутніх лікарів у студентів ЕГ і КГ на формувальному етапі педагогічного експерименту, перевіримо, чи справді сформовані ЕГ і КГ з указаними поділами за рівнями сформованості інформаційної культури майбутніх лікарів на констатувальному етапі педагогічного експерименту не мають статистично вагомих відмінностей і можуть розглядатися як рівнозначні за складом.

Скористаємося критерієм К. Пірсона $\chi^{2}$, його $\chi_{\text {емпір. }}^{2}$ визначимо за формулою:

$$
\chi_{\text {емпір. }}^{2}=N \cdot M \cdot \sum_{i=1}^{L} \frac{\left(\frac{n_{i}}{N}-\frac{m_{i}}{M}\right)^{2}}{n_{i}+m_{i}}
$$

де $N$ i $M$ - кількість майбутніх лікарів ЕГ і КГ;

$n_{i}, m_{i}$ - кількість майбутніх лікарів ЕГ і КГ, які посідають $i$-тий рівень сформованості інформаційної культури майбутнього лікаря у студентів ЕГ і КГ на констатувальному етапі педагогічного експерименту;

$L$ - кількість рівнів.

Критерій К. Пірсона $\chi^{2}$ дає змогу доказати справедливість нульової гіпотези $H_{0}$ про достовірність збігу сформованості інформаційної культури майбутніх лікарів у ЕГ і КГ на констатувальному етапі педагогічного експерименту.

Охарактеризуємо гіпотези:

$H_{0}$ - припустимо, що розподіл респондентів за рівнями сформованості інформаційної культури майбутнього лікаря в ЕГ і КГ є однаковим.

$H_{1}$ - рівень сформованості інформаційної культури майбутнього лікаря в респондентів ЕГ і КГ є неоднаковим.

Найдемо $\chi_{\text {емпір. }}^{2}$ для респондентів ЕГ і КГ на констатувальному етапі педагогічного експерименту для рівнів сформованості інформаційної культури майбутнього лікаря в ЕГ і КГ.

Таблиця 2

Значення $\chi_{\text {eмпір. }}^{2}$, добутих на констатувальному етапі педагогічного експерименту для рівнів сформованості інформаційної культури майбутнього лікаря в ЕГ і КГ

\begin{tabular}{|c|c|c|}
\hline $\begin{array}{c}\text { Компоненти сформованості } \\
\text { інформаційної культури май- } \\
\text { бутнього лікаря } \\
\end{array}$ & $\chi_{\text {емпір. }}^{2}$ & $\chi_{\text {крит. }}^{2}$ \\
\hline Інформаційний & 0,090 & \multirow{6}{*}{5,991} \\
\hline Техніко-технологічний & 0,113 & \\
\hline Загальнофізичний & 0,044 & \\
\hline Творчий & 0,091 & \\
\hline Рефлексивний & 0,076 & \\
\hline Вербальний & 0,069 & \\
\hline
\end{tabular}

Підставляючи дані 3 табл. 1 у формулу (1), y Microsoft Excel 2016 знайдемо результати, котрі занесемо в табл. 2.

Із таблиці [7, с. 181] найдемо $\chi_{\text {крит. }}^{2}$ для рівня $\alpha=0,05$ і числа ступенів свободи $v=3-1=2$. Знайшли $\chi_{\text {крит. }(\alpha=0.05)}^{2}$, занесемо його в табл. 2 .

Як бачимо 3 табл. $2, \chi_{\text {емпір. }}^{2} \chi_{\text {крит. }}^{2}$ Це дає змогу зробити висновок про якісно однаковий поділ майбутніх лікарів у ЕГ і КГ.

Результати опитування викладачів кафедри біологічної фізики, медичної апаратури та інформатики також підтвердили ці висновки.

Рівень розвитку інформаційної культури майбутнього лікаря оцінювався за допомогою вхідного, проміжного та підсумкового тестування. Завдання в тесті підбиралися відповідно до теорії Георга Раша, застосування якої дає змогу включити в тест лише ті питання, що є валідними та надійними. Окрім того, у тест включаються лише ті завдання, що не потрапляють у діапазон занадто легких (завдання, що виконуються всіма учасниками тестування на $100 \%$ ) і занадто складних (ніхто не зміг виконати завдання). Для відбору необхідних питань і завдань було проведено тестування серед студентів медичного факультету № 1, медичного факультету № 2 і стоматологічного факультету 3 напрямів підготовки 222 «Медицина», 228 «Педіатрія», 225 «Медичнапсихологія».

Також під час констатувального етапу педагогічного експерименту оцінювалася комунікабельності студентів на основі тесту В. Ряховського [11], в якому передбачено сім рівнів: явна некомунікабельність, замкнутість, товариськість до певної міри, нормальна комунікабельність, високий рівень товариськості, надмірна товариськість, хвороблива комунікабельність. Тут високий рівень - четвертий рівень, середній рівень - третій і п'ятий рівні, низький - другий і шостий рівні, дуже низький рівень - це перший і сьомий рівні.

За підсумками констатувального експерименту визначено рівні інформаційної культури майбутнього лікаря, типи компонентів у структурі інтелекту студентів. Результати констатувального експерименту підтвердили гіпотезу про недостатню сформованість інформаційної культури майбутніх лікарів. Студенти не мають навичок роботи з довідковою літературою, поштовою кореспонденцією, не володіють уміннями самостійного написання наукових статей, створення презентацій тощо. Під час оцінювання інформаційної культури студенти показали результати нижче середнього рівня: для КГ відсоток виконання завдань у середньому становив 33\%, для ЕГ - 35\%. Діагностика креативності студентів показала, що в групах ЕГ і КГ порівняні за значеннями показники переважають середній рівень творчого складника інформаційної культури. 
Організаційно-педагогічні умови та модель формування інформаційної культури майбутніх лікарів засобами математичного моделювання були представлені в дослідженні низкою вимог із боку IOC медичного ЗВО.

Формувальний етап дослідження здійснювався в рамках інформаційної підготовки майбутніх лікарів упродовж 2017-2020 pp. і був спрямований на визначення міри впливу інформаційної підготовки студентів на формування їхньої загальної інформаційної культури.

Під час відбору та розроблення авторських технологій значна увага приділялася специфіці психологічних і соціальних установок студентів, які були виявлені під час спостережень за студентами на заняттях медичної інформатики, а також у межах проведеного анкетування. Так, результати педагогічних досліджень показали, що майбутні лікарі під час навчальної діяльності найчастіше керуються соціальними (зовнішніми), ніж індивідуальними (внутрішніми), мотивами. Між тим факт усвідомлення соціальної необхідності у вивченні ІКТ зовсім не полегшує студентам життя, на нашу думку, оскільки не завжди сприяє пізнавальній активності, a отже, їхня діяльність щодо інформаційної культури, зумовлена зовнішніми мотивами, не завжди носить свідомо-пізнавальний характер. Водночас усвідомлена пізнавальна діяльність студента сприяє найбільшій продуктивності й ефективності його навчання. У зв'язку із цим у процесі розроблення методик, спрямованих на формування інформаційної культури майбутнього лікаря під час навчання медичній інформатиці, основний акцент робився на технологіях, спрямованих на формування (підтримки) зовнішніх (соціальних) мотивів студентів, а також формування у них внутрішніх (свідомопізнавальних) мотивів відносно інформаційної культури майбутніх лікарів.

Результати виявлення у студентів ЕГ і КГ показників сформованості інформаційної культури майбутнього лікаря за критеріями представлено в табл. 3.

Результати формувального етапу порівнювалися 3 результатами діагностики констатувального етапу педагогічного дослідження. Це дало змогу побачити динаміку сформованості інформаційної культури майбутнього лікаря у студентів ЕГ і КГ (рис. 1).

Підсумкова діагностика показала, що в ЕГ відбулися зміни в бік підвищення високого рівня сформованості інформаційної культури майбутнього лікаря.

\section{Результати виявлення у студентів ЕГ і КГ показників сформованості інформаційної культури майбутнього лікаря за критеріями (червень 2020 р., формувальний етап педагогічного експерименту)}

\begin{tabular}{|c|c|c|c|c|c|c|c|}
\hline \multirow[b]{3}{*}{ Групи } & \multirow{3}{*}{$\begin{array}{c}\text { Загальна } \\
\text { кількість } \\
\text { студентів } \\
\text { у групі }\end{array}$} & \multicolumn{6}{|c|}{ Рівні } \\
\hline & & \multicolumn{2}{|c|}{ низький } & \multicolumn{2}{|c|}{ середній } & \multicolumn{2}{|c|}{ високий } \\
\hline & & Кількість & $\begin{array}{c}\text { \% від загаль- } \\
\text { ної кількості } \\
\text { студентів }\end{array}$ & Кількість & $\begin{array}{c}\text { \% від загаль- } \\
\text { ної кількості } \\
\text { студентів }\end{array}$ & Кількість & $\begin{array}{c}\text { \% від загаль- } \\
\text { ної кількості } \\
\text { студентів }\end{array}$ \\
\hline \multicolumn{8}{|c|}{ за інформаційним критерієм } \\
\hline $\mathrm{E} \Gamma$ & 219 & 63 & 28,77 & 103 & 47,03 & 53 & 24,20 \\
\hline КГ & 215 & 109 & 50,70 & 91 & 42,32 & 15 & 6,98 \\
\hline \multicolumn{8}{|c|}{ за техніко-технологічним критерієм } \\
\hline $\mathrm{E} \Gamma$ & 219 & 64 & 29,22 & 108 & 49,32 & 47 & 21,46 \\
\hline КГ & 215 & 107 & 49,77 & 98 & 45,58 & 10 & 4,65 \\
\hline \multicolumn{8}{|c|}{ за загальнофізичним критерієм } \\
\hline $\mathrm{E} \Gamma$ & 219 & 63 & 28,77 & 107 & 48,86 & 49 & 22,37 \\
\hline КГ & 215 & 106 & 49,30 & 100 & 46,51 & 9 & 4,19 \\
\hline \multicolumn{8}{|c|}{ за творчим критерієм } \\
\hline $\mathrm{E} \Gamma$ & 219 & 69 & 31,51 & 103 & 47,03 & 47 & 21,46 \\
\hline КГ & 215 & 109 & 50,70 & 94 & 43,72 & 12 & 5,58 \\
\hline \multicolumn{8}{|c|}{ за рефлексивним критерієм } \\
\hline ЕГ & 219 & 67 & 30,59 & 105 & 47,95 & 47 & 21,46 \\
\hline КГ & 215 & 108 & 50,23 & 96 & 44,72 & 11 & 5,12 \\
\hline \multicolumn{8}{|c|}{ за вербальним критерієм } \\
\hline $\mathrm{E} \Gamma$ & 219 & 67 & 30,59 & 105 & 47,95 & 47 & 21,46 \\
\hline КГ & 215 & 111 & 51,63 & 94 & 43,72 & 10 & 4,65 \\
\hline
\end{tabular}


ЕГ низьжий (констатувальний)

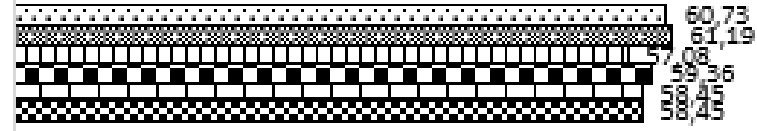

Eг низький (формувальний)

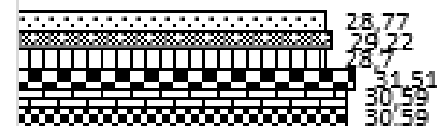

КГ низький (констатувальний)

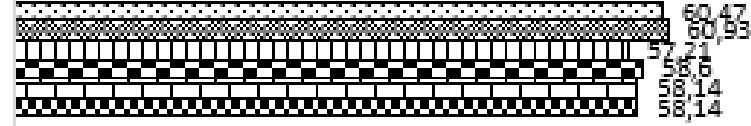

кг низький (формувальний)

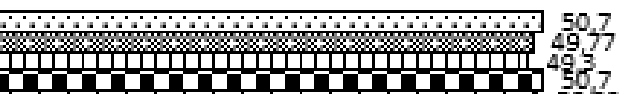

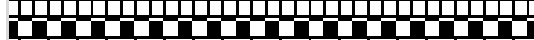

\section{7}

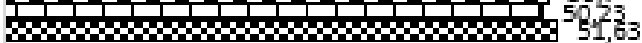

Ег середній (констатувальний)

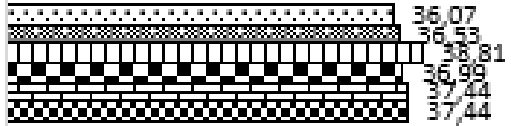

Eг середній (формувальний)

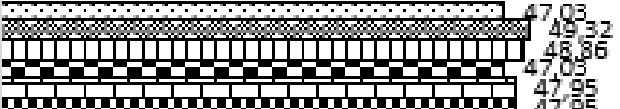

КГ середній (констатувальний)

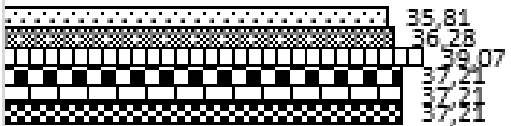

кг середній (формувальний)

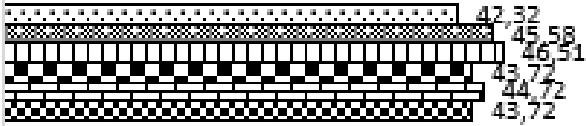

EГ високий (констатувальний)

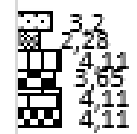

Eг високий (формувальний)

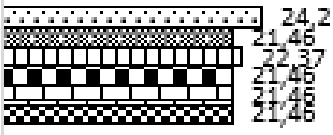

КГ високий (констатувальний)

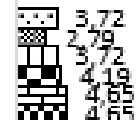

Кг високий (формувальний)

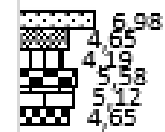

$\begin{array}{llllllll}0 & 10 & 20 & 30 & 40 & 50 & 60 & 70\end{array}$

\begin{tabular}{|c|c|}
\hline 囚Інформаційний & 圈 Техніко-технологічний \\
\hline шЗагальнофізичний & 口 Творчий \\
\hline 曰Рефлексивний & ш Вербальний \\
\hline
\end{tabular}

Рис. 1. Рівні зведених даних за шістьма компонентами інформаційної культури майбутнього лікаря в ЕГ і КГ на констатувальному та формувальному етапах педагогічного експерименту (\%) 
Із метою статистичного опрацювання результатів педагогічного експерименту виконано зіставлення рівня розвитку інформаційної культури майбутнього лікаря в ЕГ і КГ за критерієм узгодженості $\chi^{2} K$. Пірсона, емпіричне значення якого обчислюється за формулою (1).

Критерій згоди $\chi^{2}$ К. Пірсона дає змогу перевірити справедливість нульової гіпотези.

Знайдемо $\chi_{\text {емпір. }}^{2}$. етапі експерименту для рівнів інформаційної культури майбутнього лікаря.

Підставляючи дані з табл. 3 у формулу (1), за допомогою Microsoft Excel 2016 одержимо результати, котрі занесемо в табл. 4.

Порівняємо критичні значення $\chi_{\text {крит. }}^{2} \chi_{\text {емпір. }}^{2}$

Таблиця 4

Значення $\chi_{\text {емпір. }}^{2}$ здобуте на формувальному етапі педагогічного експерименту для компонентів сформованості інформаційної культури майбутнього лікаря в ЕГ і КГ

\begin{tabular}{|c|c|c|}
\hline $\begin{array}{c}\text { Компоненти сформованості } \\
\text { інформаційної культури } \\
\text { майбутнього лікаря }\end{array}$ & $\chi_{\text {eмпір. }}^{2}$ & $\chi_{\text {крит. }}^{2}$ \\
\hline Інформаційний & 34,246 & \multirow{6}{*}{5,991} \\
\hline Техніко-технологічний & 35,282 & \\
\hline Загальнофізичний & 38,730 & \\
\hline Творчий & 30,128 & \\
\hline Рефлексивний & 32,319 & \\
\hline Вербальний & 35,468 & \\
\hline
\end{tabular}

Як видно 3 табл. $4, \chi_{\text {емпір. }}^{2} \chi_{\text {крит. }}^{2}$ Це дає змогу прийняти альтернативну гіпотезу $H_{1}$ та дійти висновку: зміни в рівнях сформованості інформаційної культури майбутнього лікаря в ЕГ і КГ $е$ не випадковим явищем, а зумовлені реалізацією організаційно-педагогічних умов і сконструйованою моделлю формування інформаційної культури майбутнього лікаря в ЕГ.

Висновки і перспективи подальших розробок у цьому напрямі. Проведене дослідження дало змогу зробити висновок про можливість конструювання організаційно-педагогічних умов, що сприяють формуванню досліджуваної якості за напрямами: підвищення якості викладання загаль- них і спеціальних дисциплін, співвіднесених із формуванням інформаційної культури професійної діяльності майбутнього фахівця; здійснення цільового планування та реалізації заходів, спрямованих на формування досліджуваної якості; впровадження у навчання проєктно-гуманітарних технологій, що найбільшою мірою сприяють формуванню інформаційної культури майбутнього лікаря на основі компетентнісного підходу.

Дослідження свідчить, що проблема, котра виникає у зв'язку 3 широким розповсюдженням сучасних IКТ, окрім очевидних для всіх технічного та методичного боків, має ще один, який частіше залишається в тіні, але не менш важливий аспект - гуманітарний. Усвідомлюючи важливість інформаційного складника сучасного життя, неминучість і гостру необхідність якнайшвидшого входження у загальносвітовий інформаційний простір, не можна не розуміти того, що це передбачає підвищення не просто рівня інформаційної культури, а й цілеспрямоване підвищення рівня загальної культури майбутнього лікаря. Кожному студенту будуть необхідні не лише навички використання нових IКT, а й загальнокультурні навички комунікації, планування своєї діяльності тощо. Отже, сучасний фахівець, що діє в умовах використання IКТ, повинен мати такі характеристики: комп'ютерну грамотність, комп'ютерну освіченість, інформаційну компетентність. Проблема формування інформаційної культури майбутнього лікаря вимагає глибокого вивчення. Для iï успішного розв'язання необхідне впровадження в освітній процес спеціальних механізмів формування інформаційної культури, орієнтація студентів на дослідницьку пошукову діяльність.

Подальша дослідницька робота може бути присвячена виявленню можливостей інформаційного освітнього середовища медичного ЗВО, що постійно розвивається; пошуку оптимальних методів і засобів модульного навчання у формуванні інформаційної культури майбутнього лікаря; підготовці професорсько-викладацького складу до реалізації модульно-компетентнісного підходу у формуванні інформаційної культури професійної діяльності майбутнього лікаря.

\section{ЛITEPATУРА}

1. Виноградов В.А., Скворцов Л.В. Создание информационной культуры для Европы. Теория и практика общественно-научной информатики : доклад на VI конф. ЕКССИД, 23-25 марта 1991 г. Кантербери, Великобритания, 1991. С. 5-29.

2. Воловик П.М. Теорія ймовірностей і математична статистика в педагогіці : монографія. Хмельницький : ХГПА, 2010. 250 с.

3. Гончаренко С.У. Педагогічні дослідження: методичні поради молодим науковцям. Київ ; Вінниця : Вінниця, 2008. $278 \mathrm{c}$.

4. Гуревич Р.С. Інформаційна культура - важлива складова загальної культури особистості. Сучасні інформаційні технології та інноваційні методики навчання у підготовці фахівиів: методологія, теорія, досвід, проблеми. 2004. № 4. С. 42-47. 
5. Підготовка майбутніх учителів в освітньо-інформаційному середовищі закладів вищої освіти засобами інформаційно-комунікаційних технологій : монографія. / Р.С. Гуревич та ін. ; за ред. академіка НАПН України Р.С. Гуревича. Вінниця : Планер, 2019. 564 с.

6. Клименюк О.В. Виклад та оформлення результатів наукового дослідження : авторський підручник. Ніжин : Аспект-Поліграф, 2007. 398 с.

7. Коношевський Л.Л., Шахіна І.Ю. Обробка психологічних досліджень засобами IКТ : навчальнометодичний посібник. Вінниця : Планер, 2011. 200 с.

8. Лаврентьєва Г.П., Шишкіна М.П. Методичні рекомендації з організації та проведення науковопедагогічного експерименту. Київ : ІІТЗН, 2007. 72 с.

9. Мокін Б.І., Мокін О.Б. Методологія та організація наукових досліджень : навчальний посібник. Вінниця : ВНТУ, 2014. $180 \mathrm{c.}$

10. Овчарук В.В. Експериментально-дослідницька перевірка ефективності реалізації педагогічних умов і моделі формування здоров'язберігаючої компетентності студентів технічних закладів вищої освіти. Обрії. 2018. № 2(47). С. 94-99.

11. Тест Ряховського. Свiт порад. URL: http://poradumo.pp.ua/cikave/44114-test-ryahovskogo.html.

12. Сисоєва С.О., Кристопчук Т.С. Методологія науково-педагогічних досліджень : підручник. Рівне : Волинські обереги, 2013. 360 с.

13. Українська людина в європейському світі: виміри ідентичності : навчальний посібник / Т.С. Смовженко та ін. ; за заг. ред. 3.Е. Скринник. Київ : УБС НБУ, 2015. 609 с.

\section{REFERENCES}

1. Vinogradov, V.A., Skvortsov, L.V. (1991). Sozdanie informatsionnoy kulturyi dlya Evropyi [Creation of an information culture for Europe]. Proceedings of the Teoriya i praktika obschestv-nauchn. Informatiki: doklad na VI konferentsii EKSSID (Velikobritaniya, Kanterberi, Mar. 23-25, 1991), Kanterberi, pp. 5-29.

2. Volovyk, P.M. (2010). Teoriia imovirnostei i matematychna statystyka v pedahohitsi [Probability theory and mathematical statistics in pedagogy]. Khmelnytskyi: Khmelnytsky Humanitarian and Pedagogical Academy. (in Ukrainian)

3. Honcharenko, S.U. (2008) Pedahohichni doslidzhennia : metodychni porady molodym naukovtsiam [Pedagogical research: methodical advice to young scientists]. Kyiv ; Vinnytsia : DOV «Vinnytsia». (in Ukrainian)

4. Hurevych, R.S. (2004). Informatsiina kultura - vazhlyva skladova zahalnoi kultury osobystosti [Information culture is an important component of the general culture of the individual]. Suchasni informatsiini tekhnolohii ta innovatsiini metodyky navchannia u pidhotovtsi fakhivtsiv: metodolohiia, teoriia, dosvid, problem [Modern Information Technologies and Innovation Methodologies of Education in Professional Training: Methodology, Theory, Experience, Problems], vol. 4, pp. 42-47.

5. Hurevych, R.S., Kademiia, M.Yu., Boichuk, V.M., Hordiichuk, H.B., Konoshevskyi, L.L., Konoshevskyi, O.L., Opushko, N.R., \& Shestopal, O.V. (2019). Pidhotovka maibutnikh uchyteliv v osvitno-informatsiinomu seredovyshchi zakladiv vyshchoi osvity zasobamy informatsiino-komunikatsiinykh tekhnolohii [Training of future teachers in the educational and information environment of higher education institutions by means of information and communication technologies]. Vinnytsia : TOV Firma «Planer». (in Ukrainian)

6. Klymeniuk, O.V. (2007). Vyklad ta oformlennia rezultativ naukovoho doslidzhennia [Presentation and registration of research results]. Nizhyn : Aspekt-Polihraf. (in Ukrainian)

7. Konoshevskyi, L.L., Shakhina, I.Yu. (2011). Obrobka psykholohichnykh doslidzhen zasobamy IKT [Processing of psychological research by means of information and communication technologies] Vinnytsia : TOV Firma „Planer”. (in Ukrainian)

8. Lavrentieva, H.P., Shyshkina, M.P. (2007) Metodychni rekomendatsii z orhanizatsii ta provedennia naukovo-pedahohichnoho eksperymentu [Methodical recommendations for the organization and conduct of scientific and pedagogical experiment]. Kyiv: Institute of Information Technologies and Learning Tools. (in Ukrainian)

9. Mokin, B.I., Mokin, O.B. (2014). Metodolohiia ta orhanizatsiia naukovykh doslidzhen [Methodology and organization of scientific research]. Vinnytsia: Vinnytsia National Technical University. (in Ukrainian)

10. Ovcharuk, V.V. (2018). Eksperymentalno-doslidnytska perevirka efektyvnosti realizatsii pedahohichnykh umov i modeli formuvannia zdoroviazberihaiuchoi kompetentnosti studentiv tekhnichnykh zakladiv vyshchoi osvity [Experimental-research check of efficiency of realization of pedagogical conditions and model of formation of health-preserving competence of students of technical establishments of higher education]. Scientific-pedagogical journal "Horizons", vol. 2, no. 47, pp. 94-99.

11. Test Riakhovskoho [Ryahovsky's test]. Retrieved from http://poradumo.pp.ua/cikave/44114-test-ryahovskogo. html.

12. Sysoieva, S.O., \& Krystopchuk, T.Ye. (2013). Metodolohiia naukovo-pedahohichnykh doslidzhen [Methodology of scientific and pedagogical research]. Rivne: Volynski oberehy. (in Ukrainian)

13. Smovzhenko, T.S., \& Skrynnyk, Z.E. (2015). Ukrainska liudyna v yevropeiskomu sviti: vymiry identychnosti [Ukrainian man in the European world: dimensions of identity]. Kyiv: UBS NBU. (in Ukrainian). 